\title{
Trends in Complex Analysis, Differential Geometry and Mathematical Physics
}


This page intentionally left blank 


\title{
Trends in Complex Analysis, Differential Geometry and Mathematical Physics
}

\section{Proceedings of the 6th International Workshop on Complex Structures and Vector Fields}

\author{
St Konstantın, Bulgarıa $\quad 3-6$ September 2002
}

\author{
Editors \\ Stancho Dımıev \\ Bulgarıan Academy of Sciences Bulgarıa
}

Koueı Sekıgawa

Nugata Unıversıty Japan 


\section{Published by}

World Scientufic Publishing Co Pte Ltd

5 Toh Tuck Link Singapore 596224

USA office Suite 2021060 Main Street River Edge NJ 07661

UK office 57 Shelton Street Covent Garden London WC2H 9HE

\section{Britısh Library Catalogung in Publıcation Data}

A catalogue record for this book is avallable from the Bntısh Library

\section{TRENDS IN COMPLEX ANALYSIS, DIFFERENTIAL GEOMETRY AND MATHEMATICAL PHYSICS \\ Proceedings of the Suxth International Workshop on Complex Structures and Vector Fields \\ Copyright $@ 2003$ by World Scientific Publishing Co Pte Ltd \\ All nghts reserved This book or parts thereof may not be reproduced in any form or by any means electronic or mechanical including photocopying recording or any information storage and retrieval system now known or to be invented without written permission from the Publisher}

\footnotetext{
For photocopying of material in this volume please pay a copying fee through the Copynght Clearance Center Inc 222 Rosewood Drive Danvers MA 01923 USA In this case permission to photocopy is not required from the publisher
}

ISBN 9812384529 


\title{
SIXTH INTERNATIONAL WORKSHOP ON COMPLEX STRUCTURES AND VECTOR FIELDS
}

\author{
September 3-7, 2002, Varna, Bulgarıa
}

\section{CONTRIBUTED COMMUNICATIONS}

I K H Spallek

Spaces and fields - Reality truth and fiction -

2 K Sekıgawa

Notes on Kahler surfaces with distınct constant Rıccı eıgenvalues

3 G Ganchev

Involutıve distributions of codımension one in Kaehler manıfolds

4 V Milusheva (G Ganchev)

Two dımensıonal surfaces in Euclıdean space generatıng semı-symmetric hy persurfaces

5 M Manev

On hypercomplex pseudo Hermitian manıfolds

$6 \mathrm{~S}$ Maeda

Circles and Kaehler immersıons

7 T Adachı

Kaehler magnetıc fields on product of complex hyperbolıc spaces

8 A Yamada

Integrability of almost quaternıonic manıfolds

9 V Cristea

Oka s theorem for superholomorphic functions and superforms

$10 \mathrm{E}$ Corel

Fuchs lıke ،elation for regular connections on a compact Riemann surface

$11 \mathrm{H}$ Tasakı

Poincare formulae of submanifolds in complex space forms

12 H Kamada

Tıme-lıke kıllıng vector fields on compact scalar flat Kaehler surfaces 


\section{G Nakova}

Curvature tensors in the basic classes of real isotropic hypersurfaces of Kaehler manifold with B metric

14 M Hristov

Hermitian-like curvatures of the four basic classes of real hypersurfaces of a complex space form

15 G Nakova

Curvature tensors on almost contact manıfolds with B metric

\section{$16 \mathrm{~S}$ Dimiev}

Antı cyclic structures

17 B Iliev

On operator differentration in the action principle in quantum field theory

18 V Molotkov

Differential calculus in categories 
To Professor Alfred Gray,

In Memoriam

\section{PREFACE}

This book presents the sixth conference of the international interdisciplinary workshop called in short the sixth international workshop on Complex Structures and Vector Fields This time many specialists on Complex Analysıs Differential Geometry and Mathematical Physics gathered together in Sunny Beach Varna Bulgarıa, September 3-7 2002 Besıdes some traditıonal partıcıpants from Germany and Russia there ware different new participants from Japan and France and especially from Balkan countries like Turkey Romania and Bulgaria a natu ral environment for stımulatıng the scientific actıvity in this part of Europe The publıshed papers reflect the fundamental orientation of the workshop during the last 10 years of its existence namely the facility of scientific investigations and the communications between mathematicians from different big and small countries

The book is dedicated to the dear memory of Professor Alfred Gary unforgettable friendly fellow of many participants of this Workshop

The Editors would like to express here their gratitude to Professor T Oguro for his outstanding cooperation and efforts in the arrangement of this volume and Professors S Manoff for his help 
This page intentionally left blank 


\section{CONTENTS}

Preface vil

Kahler magnetic fields on a product of complex hyperbolıc spaces T Adach

Real analytic almost complex manıfolds

$L N$ Apostolova

Fuchs-lıke relation for regular connections on a compact Riemann surface

E Corel

Oka s theorem for superholomorphic functions and superforms

VG Cristea

Involutıve distrıbutıons of codımension one in Kaehler manıfolds

$G$ Ganchev

On the theory of two-dımensıonal surfaces in Euclidean space

$G$ Ganchev and $V$ Milousheva

On hypercomplex pseudo hermitian manifolds

$K$ Gribachev M Manev and S Dimuer

Hermitsan-lıke curvatures of the four basıc classes of real hypersurfaces of a complex space form

$M$ Hristov

On operator differentıation in the action princıple in quantum field theory

B Z Iliev

Tıme lıke kıllıng vector fields on compact ındefınıte Kahler surfaces

H Kamada

Three theorems on isotropic immersions

$S$ Maeda

Circles and Kahler immersıons

$S$ Maeda and T Adach

On the Meilıkhson theorem

MS Marinov

Diffeomorphısms preserving a skew-symmetric curvature operator

in Riemannıan geometry

$S M$ Marunov 
Curvature tensors on almost contact manifolds with B metric

G Nakova

Curvature tensors in the basic classes of real isotropic hypersurfaces

of a Kaehler manifold with B metric

G Nakova

A function of direction in a Weyl subspace associated with a set of orthogonal vector fields

A Ozdeğer

Complex structures and the quark confinement

I B Pestov

Characterizations of parallel isometric immersions of compact rank one symmetric spaces into space forms by circles

K Suizu

Poincare formulae of submanıfolds in complex space forms

H Tasakı

Curvature operators in the relatıvity

$\checkmark$ Videv and $Y$ Tsankov

On integrabilıty of almost quaternıonıc manıfolds

A Yamada 